\title{
Interpretation of the ECHR in light of the Vienna Convention on the Law of Treaties
}

\author{
Professor Geir Ulfstein, PluriCourts, University of Oslo ${ }^{1}$
}

\section{Introduction}

The European Convention on Human Rights (ECHR, or the Convention) was adopted to ensure effective protection of human rights in Europe. The Convention has, through the European Court of Human Rights (the Court, or the ECtHR), had a transformative influence on the legal order in European States. ${ }^{2}$ However, the Court has been subject to increasing criticism. ${ }^{3}$ Some member States think that the Court has gone too far: that it has become an activist court. They reproach the Court for excessive encroachment on their national sovereignty, at the expense of national democratic decision-making and judicial practice.

A fundamental basis for the legitimacy of the ECtHR, as seen from member States, is that its judgments are based on generally accepted principles of treaty interpretation. This was recently emphasized by the Copenhagen Declaration, adopted by the Committee of Ministers' High-Level Conference on 13 April 2018. The Declaration also underscores the principle of subsidiarity, i.e. the primary role of domestic organs in protecting ECHR rights. Moreover, the quality of the Court's reasoning, and, in particular, the clarity and consistency of the judgments are accentuated. ${ }^{4}$ Finally, the Council of Europe Steering Committee for Human Rights (CDDH) has stressed the importance of interpreting the Convention in accordance with member States' commitments under other treaties and customary international law. ${ }^{5}$

My focus is on the Court's methods of interpretation in light of the criticism against the ECtHR. I examine to what extent the Court respects the international legal principles of treaty

\footnotetext{
${ }^{1}$ This article was supported by the Research Council of Norway through its Centres of Excellence Funding Scheme, project number 223274 PluriCourts - The Legitimacy of the International Judiciary.

${ }^{2} \mathrm{H}$ Keller and A Stone Sweet, 'The Reception of the ECHR in National Legal Orders' in H Keller and A Stone Sweet (eds), A Europe of Rights (Oxford University Press, Oxford 2008) 3-31, 4 ('broad and pervasive impact'); J Gerards, 'The European Court of Human Rights and the National Courts: giving Shape to the Notion of 'Shared Responsibility" in J Gerards and J Fleuren (eds), Implementation of the European Convention on Human Rights and of the Judgments of the ECtHR in National case-law: a Comparative Analysis (Intersentia, Cambridge 2014) 13-95, ('a huge impact on national law, national judicial decision making and national constitutional division of competences').

${ }^{3}$ See TD Campbell, KD Ewing and A Tomkins, Sceptical Essays on Human Rights (Oxford University Press, Oxford 2001); S Flogaïtis, T Zwart and J Fraser, The European Court of Human Rights and its Discontents: Turning Criticism into Strength (Edward Elgar, Cheltenham 2013); and P Popelier, S Lambrecht and K Lemmens, Criticism of the European Court of Human Rights : shifting the convention system : counter-dynamics at the national and EU level (Law and cosmopolitan values, Intersentia, Cambridge 2016)MR Madsen, "The Challenging Authority of the European Court of Human Rights; From Cold War Legal Diplomacy to the Brighton Declaration and Backlash 'Law and Contemporary Problems 7912016 141-179.

${ }^{4}$ Copenhagen Declaration, (http://www.justitsministeriet.dk/sites/default/files/media/Forsidebilleder_2018/copenhagen_declaration.pdf), paragraphs 26, 27 and 29.

${ }^{5}$ Council of Europe, The Longer-Term Future of the System of the European Convention on Human Rights. Report of the Steering Committee for Human Rights (CDDH) adopted on 11 December 2015 (Council of Europe, Strasbourg 2016), paragraph 187.
} 
interpretation, as reflected in the 1969 Vienna Convention on the Law of Treaties (the VCLT), both explicitly and in practice. I ask whether the ECtHR is able to accommodate the ECHR purposes within the VCLT framework. But I also question to what extent the VCLT restrains the interpretation of the ECHR in accordance with the concerns of member States. Moreover, I discuss the Court's use of the margin of appreciation, as an aspect of the principle of subsidiarity.

It would have been impossible with a comprehensive examination of all ECtHR cases raising issues of interpretation. Instead, I discuss landmark judgments by the Court debated in the literature on the relevant issues of interpretation. I include subsequent cases referring to such judgments, found by search in the Court's HUDOC database. I have also consulted recent case law by the ECtHR's Grand Chamber from 2014 to mid-2018.

I first discuss the extent to which the Court explicitly supports the applicability of the VCLT (section 2). Then, I reflect on how specific practices developed by the Court fit with the VCLT, i.e. effective and evolutive interpretation (sections 3 and 4). I go on to discuss the Court's use of the margin of appreciation (section 5). Moreover, I examine the Court's interpretation of the ECHR in light of other commitments under international law, including decisions by the European Union and the UN Security Council (section 6). Finally, I draw some conclusions (section 7).

\section{The Vienna Convention on the Law of Treaties}

The VCLT sets out the rules of interpretation in its Articles 31 to 33. The International Court of Justice (the ICJ) has considered these rules to reflect customary international law. ${ }^{6}$ However, it has been argued that the principles of treaty interpretation apply to the relationship between States parties, but do not sufficiently take into account the special character of treaties protecting individuals. For example, it has been contended that the VCLT principles 'must be applied with caution in view of the special features of the Convention [i.e. the ECHR]'. ${ }^{7}$ Our question in this section is the extent to which the ECtHR recognizes these rules of interpretation for the ECHR.

The Court has addressed the VCLT rules of interpretation in several cases. In Demir and Baykara (2008), the Court stated that it is 'guided mainly by the rules of interpretation provided for in articles 31 to 33 of the Vienna Convention on the Law of Treaties'. This is followed by the standard formulation that '[s]ince the Convention is first and foremost a system for the protection of human rights, the Court must interpret and apply it in a manner which renders its rights practical and effective, not theoretical and illusory' ${ }^{8}$ It is worth noting that the Court felt a need to qualify the application of the VCLT articles 31 to 33 both by using the term 'mainly' and by adding that the ECHR should be interpreted in a way that renders it 'practical and effective'.

\footnotetext{
${ }^{6}$ Arbitral Award of 31 July 1989, ICJ Rep. 1991, 53 at 70.

${ }^{7}$ FG Jacobs and others, The European Convention on Human Rights (6th ed. Bernadette Rainey, Elizabeth Wicks, and Clare Ovey. edn Oxford University Press, Oxford 2014), 67.

${ }^{8}$ Demir and Baykara v. Turkey [GC] (2008) Application no. 34503/97, paragraphs 65-66.
} 
In its subsequent practice, the Court has constantly confirmed the relevance of the Vienna Convention. But, as in the Demir and Baykara, the significance of the VCLT has been subject to qualifications. For example, in Rantsev (2010) the Court stated that the ECHR must be interpreted in the light of the VCLT. ${ }^{9}$

The Hassan case [Grand Chamber] (2014) has a more robust wording, saying that 'the starting point for the Court's examination must be its constant practice of interpreting the Convention in the light of the rules set out in the Vienna Convention on the Law of Treaties'. ${ }^{10}$ Even stronger expressions are used in Cyprus v. Turkey (2014). The Court said that '[d]espite its specific character as a human rights instrument, the Convention is an international treaty to be interpreted in accordance with the relevant norms and principles of public international law, and, in particular, in the light of the Vienna Convention on the Law of Treaties'.11

This case seems to settle that the Court sees no contradiction between the ECHR as a human rights instrument and its interpretation based on accepted canons of interpretation, where the Vienna Convention has a particular role. Consequently, the concerns expressed in earlier case law, including in Demir and Baykara, can, according to the ECtHR, be accommodated within the bounds of the Vienna Convention. ${ }^{12}$ This is confirmed in the Al-Dulimi case (2016) and the Naït-Liman case (2018), which use a wording identical to that of Cyprus v. Turkey. ${ }^{13}$

\section{Effective interpretation}

The VCLT Article 31 (1) establishes:

A treaty shall be interpreted in good faith in accordance with the ordinary meaning to be given to the terms of the treaty in their context and in the light of its object and purpose.

The ICJ gives primacy to the treaty text: 'Interpretation must be based above all upon the text of the treaty ${ }^{14}$. But the text must, according to Article 31 (1), be interpreted in the light of the treaty's object and purpose. The object and purpose of the ECHR is clearly to protect human rights. This provides general support for the ECtHR's pursuit of rendering the ECHR 'practical and effective' ${ }^{15}$. The ICJ has held that the principle of effectiveness is 'one of the fundamental principles of interpretation of treaties' ${ }^{\prime 6}$.

\footnotetext{
${ }^{9}$ Rantsev v. Cyprus and Russia (2010), Application no. 25965/04, paragraph 273.

${ }^{10}$ Hassan v. the United Kingdom [GC] (2014), Application no. 29750/09, paragraph 100 (emphasis added).

${ }^{11}$ Cyprus v Turkey [GC] (2014), Application no. 25781/94, paragraph 23 (emphasis added)

${ }^{12}$ See DJ Harris, C Warbrick and M O'Boyle, Law of the European Convention on Human Rights (Oxford University Press, Oxford 2014), 7; B Cali, 'Specialized Rules of Treaty Interpretation: Human Rights' in DB Hollis (ed) The Oxford Guide to Treaties (Oxford University Press, Oxford 2012) 525-551, 537.

${ }^{13}$ Al-Dulimi and Montana Management Inc. v. Switzerland [GC], Application no. 5809/08 (2016), paragraph 80 and Naït-Liman v. Switzerland [GC], Application no. 51357/07 (2018), paragraph 174.

${ }^{14}$ Legality of Use of Force, (Serbia and Montenegro v. Belgium) (2004), paragraph 100.

${ }^{15}$ Harris, Warbrick and O'Boyle, Law of the European Convention on Human Rights, 7.

${ }^{16}$ Territorial Dispute (Libyan Arab Jamahiriya v. Chad) (1994), 6 at 25. See on effective interpretation, Gardiner, Treaty Interpretation 2ed (2015), 179-181
} 
An early example of the ECtHR's use of effective interpretation is the Golder [Plenary] case (1975), where the Court, without explicit basis in ECHR Article 6 on fair trial, read in a right of access to court. ${ }^{17}$ Prominent subsequent examples include Soering [Plenary] (1989) ${ }^{18}$ and Mamatkulov and Askarov (2005) ${ }^{19}$. In Soering, the Court established that Article 3 on the prohibition on torture and degrading and inhuman treatment or punishment, prohibited extradition to US death row. ${ }^{20}$ In Mamatkulov and Askarov the Court, again without explicit basis in the ECHR, held that its interim measures were binding on States parties. ${ }^{21}$ Moreover, effective interpretation is reflected in the Court's restrictive interpretation of member States' discretion to interfere with Convention rights. ${ }^{22}$

However, the Court has also established that the text of the Convention, as well as its object and purpose, may represent limitations on how far it should go in its effective interpretation.

First, the Court seeks to respect the wording of the Convention by not reading new rights into it, such as in the Johnston case (1986), where it concluded that the ECHR Article 12 on the right to marry could not be read to also contain a right to divorce. It should be added that in this case, the textual interpretation was supported by the object and purpose of this particular Article, as well as by the travaux préparatoires. ${ }^{23}$

Second, the object and purpose of the Convention may not only serve as a basis for an expansive interpretation. It may also limit how far the Court should go in imposing certain solutions on member States. One example is use of a lay jury in criminal cases. In the Taxquet case [Grand Chamber] (2010), the Court stated:

The jury exists in a variety of forms in different States, reflecting each State's history, tradition and legal culture ... This is just one example among others of the variety of legal systems existing in Europe, and it is not the Court's task to standardise them. A State's choice of a particular criminal justice system is in principle outside the scope of the supervision carried out by the Court at European level, provided that the system chosen does not contravene the principles set forth in the Convention ... ${ }^{24}$

It is important to note that the Court will respect the plurality of legal criminal systems in the member States, and that their choice of system is beyond the scope of the ECHR - only subject to basic fair trial principles according to Article 6. This means considerable freedom to States in designing their criminal procedure.

\footnotetext{
${ }^{17}$ Golder $v$ the United Kingdom [Plenary] (1975), Application no. 4451/70.

${ }^{18}$ Soering $v$ the United Kingdom [Plenary] (1989), Application no. 14038/88.

${ }^{19}$ Mamatkulov and Askarov v Turkey (2005), Applications nos. 46827/99 and 46951/99.

${ }^{20}$ Soering $v$ the United Kingdom [Plenary] (1989), paragraph 87.

${ }^{21}$ Mamatkulov and Askarov v Turkey, paragraph 102.

${ }^{22}$ Perinçek $v$ Switzerland [GC] (2015), Application no. 27510/08, paragraph 122.

${ }^{23}$ Johnston v Ireland (1986), Application no. 9697/82, paragraph 52.

${ }^{24}$ Taxquet v Belgium [GC] (2010), Application no. 926/05, paragraph 83 (emphasis added).
} 
We can conclude that the Vienna Convention does not prevent the Court from applying interpretations that ensure that the ECHR is 'practical and effective'. The Court has also accepted that there are limitations to its effective interpretation of the ECHR.

However, in light of the criticism that the Court goes too far in its intrusion on national legislative, executive and judicial freedom, two dangers should be pointed out. One is of a systemic character and the other concerns the risk of inflation of human rights protection.

The systemic concern is illustrated by a study by David Kosař and Lucas Lixinski, showing that the Court in its policing of fair trial standards to a large extent determine the structure of the domestic judiciary. ${ }^{25}$ Hence, while the Court expresses general respect for national choices of legislative, executive and judicial systems, it should take care not to undermine such national freedoms through its incremental case law.

The Court should also restrict the Convention scope in issues of a more mundane character. One recent example is the Cuenzca Zarzoso case $(2018)^{26}$. The applicant complained of noise caused by bars, pubs and discotheques in the vicinity of his home. The Court concluded that Spain had 'failed to discharge its positive obligation to guarantee the applicant's right to respect for his home and his private life, in breach of Article 8 of the Convention' ${ }^{27}$ It may be questioned whether such issues merit protection by an international human rights court, like the ECtHR.

This illustrates that the VCLT does not necessarily contain sufficient protection against the ECtHR's intrusions in what is arguably the exclusive national domain. Therefore, it is important that the Court through express interpretational statements and in its practice limit its effective interpretation of the Convention.

\section{Evolutive interpretation}

Treaties can change over time through evolutive (or 'evolutionary') interpretation. The interpretation of a treaty can change as a result of subsequent practice showing 'the agreement of the parties regarding its interpretation' (VCLT, Article 31(3)(b)). Alternatively, as acknowledged by the ICJ, the interpretation of a treaty can change on the basis of the evolutive intention of the States parties at the time of the treaty's adoption. ${ }^{28}$ This is in accordance with interpretation based on the treaty's object and purpose (VCLT, Article

\footnotetext{
25 K David and L Lixinski, 'Domestic Judicial Design by International Human Rights Courts'American Journal of International Law 10942015 713-760. See also D Kosař, 'Policing Separation of Powers: A New Role for the European Court of Human Rights?'European Constitutional Law Review 812012 33-62 and D Kosař, 'Nudging Domestic Judicial Reforms from Strasbourg: How the European Court of Human Rights shapes domestic judicial design'Utrecht Law Review 1312017 112-123.

${ }^{26}$ Cuenzca Zarzoso v. Spain (2018), Application no. 23383/12.

${ }^{27}$ Cuenzca Zarzoso v. Spain, paragraph 51.

${ }^{28}$ Case Concerning the Dispute Regarding Navigational and Related Rights (Costa Rica v. Nicaragua), ICJ Judgment 13 July 2009, paragraph 64. See also E Bjorge, The Evolutionary Interpretation of Treaties (Oxford University Press, Oxford 2014), 5.
} 
31(1)). The Copenhagen Declaration supports that the Court gives 'appropriate consideration to present-day conditions'. ${ }^{29}$

The ECtHR generally recognizes evolutive interpretation based on subsequent State practice. In Hassan, the Court said that 'in respect of the criterion set out in Article $31 \S 3$ (b) of the Vienna Convention [ ... ], the Court has previously stated that a consistent practice on the part of the High Contracting Parties, subsequent to their ratification of the Convention, could be taken as establishing their agreement not only as regards interpretation but even to modify the text of the Convention'. ${ }^{30}$ The Al-Saadoon and Mufdhi case (2010) is interesting by the fact that the Court held that subsequent practice had modified the ECHR. The Court concluded that the internal legislation by the States parties and their acceptance on Protocols 6 and 13 on the abolition of the death penalty meant that the wording of Article 2 of the ECHR on allowing this penalty did not any longer prevent the death penalty from being regarded as inhuman or degrading treatment under Article $3 .{ }^{31}$ Hence, the ECHR was considered modified on the basis of a combination of domestic law and international instruments in the form of Protocols 6 and 13.

However, this use of subsequent practice in the Court's evolutive interpretation is exceptional. Rather than asking whether there is agreement among the States parties on an interpretation based on Article 31(3)(b), the ECtHR has based its interpretation on their evolutive intention at the adoption of the ECHR, i.e. applying the ECHR's object and purpose according to Article 31(1). ${ }^{32}$ The Court has, in its evolutive interpretation, assessed whether there exists a European consensus on the appropriate human rights standard and taken into account international instruments. ${ }^{33}$

The Tyrer case (1978) introduced the doctrine of the European Convention as a 'living instrument'. ${ }^{34}$ In this case, the Court relied on developments in member States' domestic policy. In the Marckx case (1979), the Court used, however, in addition to developments in domestic law of the member States, two conventions as a basis for stating that 'there is a clear measure of common ground in this area amongst modern societies'. ${ }^{35}$ In the Goodwin case (2002), the Court attached 'less importance to the lack of evidence of a common European

\footnotetext{
${ }^{29}$ Copenhagen Declaration, paragraph 26.

${ }^{30}$ Hassan v. the United Kingdom, para. 101.

${ }^{31}$ Al-Saadoon and Mufdhi v The United Kingdom ECHR 2010- II 61, paragraph 120. Article 2(1) reads:

'Everyone's right to life shall be protected by law. No one shall be deprived of his life intentionally save in the execution of a sentence of a court following his conviction of a crime for which this penalty is provided by law' (emphasis added).

${ }^{32}$ Harris, Warbrick and O'Boyle, Law of the European Convention on Human Rights, 8; Jacobs and others, The European Convention on Human Rights, 73; WA Schabas, The European Convention on Human Rights : A Commentary (European Convention on Human Rights. edn Oxford commentaries on international law, Oxford University Press, Oxford 2015), 48. International Law Commission, First report on subsequent agreements and subsequent practice in relation to treaty interpretation by Georg Nolte, Special Rapporteur, A/ CN.4/ 660, 19 March 2013, para 37 (footnotes omitted, emphasis added).

${ }^{33} \mathrm{~K}$ Dzehtsiarou, European Consensus and the Legitimacy of the European Court of Human Rights (Cambridge University Press, 2015), 38.

${ }^{34}$ Tyrer v. the United Kingdom, Application no. 5856/72 (1978), paragraph 31.

${ }^{35}$ Marckx v. Belgium, Application no. 6833/74 (1979), paragraph 41.
} 
approach to the resolution of the legal and practical problems posed, than to the clear and uncontested evidence of a continuing international trend in favour not only of increased social acceptance of transsexuals but of legal recognition of the new sexual identity of postoperative transsexuals' ${ }^{36}$

The Court has continued to base its evolutive interpretation on what it deems a European consensus in domestic law among member States, as well as on practice in the form of international instruments. ${ }^{37}$ As stated in the Demir and Baykara case (2008): 'The consensus emerging from specialized international instruments and from the practice of Contracting States may constitute a relevant consideration for the Court when it interprets the provisions of the Convention in specific cases'. ${ }^{38}$

However, the Court has not been consistent in its recent case law with respect to the required consensus in domestic law. In Magyar Helsinki Bizottság [Grand Chamber] (2016) the Court said that it may have regard to developments in domestic legal systems indicating a 'uniform or common approach or a developing consensus between the Contracting States in a given area. ${ }^{39}$ The Court also speaks of a 'broad consensus' ${ }^{40}$ In Naït-Liman [Grand Chamber] (2018), the Court stated that it may assess whether there exists a "European consensus" or at least a certain trend among the member States'. ${ }^{41}$

The discretionary freedom is even more outspoken when it comes to the use of international material. In the Rantsev case, the Court referred to practice by the International Criminal Tribunal for the former Yugoslavia (ICTY), but also to the Protocol to Prevent, Suppress and Punish Trafficking in Persons, especially Women and Children (the Palermo Protocol) and the European Convention on Action against Trafficking in Human Beings (the Anti-Trafficking Convention) in its interpretation of slavery, servitude, or forced and compulsory labour under article $4 .{ }^{42}$ But it did not explain the importance of these instruments and the judicial practice for the interpretation of the ECHR. Instead, it seems that the Court preferred to keep the influence of such instruments extremely vague and to allow itself absolute discretion. Such discretion has explicitly been confirmed by the Tănase [Grand Chamber] (2010), the Kiyutin (2011) and, most recently, in the A.-M.V. (2017) cases. In all three cases, the Courts said: 'It is for the Court to decide which international instruments and reports it considers relevant and how much weight to attribute to them. ${ }^{43}$

\footnotetext{
${ }^{36}$ Christine Goodwin v. the United Kingdom [Grand Chamber] Application no. 28957/95 (2002), paragraph 85.

${ }^{37}$ Dzehtsiarou, European Consensus and the Legitimacy of the European Court of Human Rights, 45-49.

${ }^{38}$ Demir and Baykara v. Turkey [Grand Chamber] Application no. $34503 / 97$ (2008), paragraph 85 (emphasis added).

${ }^{39}$ Magyar Helsinki Bizottság v. Hungary [GC] (2016), Application no. 18030/1, paragraph 138 (emphasis added).

${ }^{40}$ Magyar Helsinki Bizottság v. Hungary, paragraph 139 (emphasis added).

${ }^{41}$ Naït-Liman v. Switzerland [GC] (2018), Application no. 51357/07, paragraph 175 (emphasis added).

${ }^{42}$ Rantsev v. Cyprus and Russia (2010), Application no. 25965/04, paragraphs 278-280.

${ }^{43}$ Tănase v Moldova [GC] (2010), Application no. 7/08, paragraph 176; Kiyutin v. Russia (2011), Application no. 2700/10, paragraph 67; A.-M.V. v. Finland (2017), Application no. 53251/13.
} 
It makes sense that the ECHR was intended as a 'living instrument', justifying evolutive interpretation in accordance with Article 31 (1), also in the absence of subsequent agreement among member States. However, the characterization of the Convention as a living instrument does not say anything about the direction or degree of evolutive interpretation. What should control such interpretation?

There are good reasons for reliance on European consensus in the ECtHR's evolutive interpretation. Such practice represents objective factors, rather than the Court's subjective assessment or its own 'moral reading' of the Convention. ${ }^{44}$ This does not mean that the relevance of European practice is objective in the sense that its use is without interpretational challenges. But use of such practice is comparatively more objective than leaving complete discretion to the Court itself. Furthermore, it means that emphasis is given to development in member States, as 'masters of the treaty'. It can be seen as expressions of the collective democratic input by these States and, as such, supporting 'an effective political democracy' as stated in the preamble of the Convention. It may also promote consistency and predictability in the Court's case law.

However, unlike the requirement of agreement in Article 31(3)(b), evolutive interpretation based on Article 31(1) does not contain a comparable threshold for when the Court in effect is amending the ECHR through interpretation. The different standards applied by the Court in determining European consensus and its preferred discretionary freedom in using international instruments may make the Court vulnerable to criticism of unjustified activism, i.e. that it acts as a legislator, and not as a judicial organ. Such practice may also undermine consistency and predictability in its case law.

Therefore, the Court should differentiate between reliance on a European consensus and on other international legal instruments. It should explain how much weight it accords to, respectively, domestic practice and international instruments. The Court should also more clearly define what it means by a European consensus. In addition, it should specify the emphasis given to different international legal instruments, whether they are global or European, or binding or non-binding. Finally, rather than emphasizing its discretion in the reliance on different instruments, it should clarify a policy for such choices.

\section{Margin of appreciation}

The Court has two ways of alleviating the concerns of member States about too much intrusion in national sovereignty. It may, as discussed in sections 3 and 4, restrict the substantive scope of the ECHR by limiting the effective and evolutive interpretation of the Convention. Alternatively, it may leave a discretion to the States on domestic implementation of the ECHR through the margin of interpretation.

\footnotetext{
${ }^{44}$ Dzehtsiarou, European Consensus and the Legitimacy of the European Court of Human Rights, 142. On a moral reading, see G Letsas, 'The ECHR as a Living Instrument: Its Meaning and Legitimacy' in A Føllesdal, B Peters and G Ulfstein (eds), Constituting Europe: the European Court of Human Rights in a National, European and Global Context (Cambridge University Press, 2013) 106-142.
} 
The margin of appreciation is a standard of review - a deference - applied by the Court in its examination of decisions taken at the national level. ${ }^{45}$ The margin of appreciation is an aspect of the principle of subsidiarity. Subsidiarity establishes a rebuttable presumption that decision-making should be taken at the lower level, unless it is more effectively or efficiently performed at the higher level. ${ }^{46}$

The margin applied by the ECtHR has similarities to standards of review applied by domestic courts in their administrative review of acts from the executive, and even constitutional review of legislative acts. Standards of review are also applied by international courts and tribunals beyond the ECtHR, when examining decisions taken at the national level. ${ }^{47}$ For example, the WTO Appellate Body allows States a certain discretion when establishing measures that may have effects on trade. ${ }^{48}$ Standards of review have been referred to in investment arbitration ${ }^{49}$ and by the International Tribunal for the Law of the Sea (ITLOS). ${ }^{50}$ The ICJ allowed some discretion to national decision-making in the Whaling case (2014). ${ }^{51}$ However, the support of forms of deference in human rights tribunals has not been uniform. The Inter-American Court of Human Rights (IACtHR) and the United Nations human rights treaty bodies have so far been skeptical to the use of the margin of appreciation - at least expressly. But use of the margin has been called for by several commentators. ${ }^{52}$

${ }^{45} \mathrm{G}$ Letsas, A theory of interpretation of the European Convention on Human Rights (Oxford University Press, Oxford 2007), 80-81; A Legg, The Margin of Appreciation in International Human Rights Law: Deference and Proportionality (Oxford University Press, Oxford 2012). See also G Letsas, 'Two Concepts of the Margin of Appreciation'Oxford Journal of legal Studies 2642006 705-732 and Legg, The Margin of Appreciation in International Human Rights Law: Deference and Proportionality.

${ }^{46}$ See A Føllesdal, 'Survey article: Subsidiarity'The Journal of Political Philosophy 621998 190-218 PG Carozza, 'Subsidiarity as a Structural Principle of International Human Rights Law'American Journal of International Law 9712003 38-79, I Feichtner, 'Subsidiarity'Max Planck Encyclopedia of Public International Law (2009) , GL Neuman, 'Subsidiarity' in D Shelton (ed) The Oxford Handbook of International Human Rights Law (Oxford University Press, Oxford 2013) 360-379, A Follesdal, 'Subsidiarity and international human rights courts: respecting self-governance and protecting human rights - or neither?(Subsidiarity in Global Governance)'Law and Contemporary Problems 7922016 147-163, 148 and M Jachtenfuchs and N Krisch, 'Subsidiarity in global governance'ibid1-26, 6.

${ }^{47}$ L Gruszczynski and WG Werner, 'Introduction' in L Gruszczynski and WG Werner (eds), Deference in international courts and tribunals : standard of review and margin of appreciation (Oxford University Press, Oxford 2014) 1-15 and Y Shany, 'Toward a General Margin of Appreciation Doctrine in International Law?'Eur J Int Law 1652005 907-940.

${ }^{48} \mathrm{~J}$ Bohanes and N Lockhart, 'Standard Review in WTO Law' in D Bethlehem and others (eds), The Oxford Handbook of International Trade Law (Oxford University Press, 2009) 378-437.

${ }^{49} \mathrm{C}$ Henckels, Proportionality and Deference in Investor-State Arbitration : Balancing Investment Protection and Regulatory Autonomy (Cambridge Studies in International and Comparative Law, Cambridge University Press, 2015), 7.

${ }^{50} \mathrm{R}$ Rayfuse, 'Standard of Review in the International Tribunal for the Law of the Sea' in L Gruszczynski and WG Werner (eds), Deference in international courts and tribunals : standard of review and margin of appreciation (Oxford University Press, Oxford 2014) 337-354.

${ }^{51}$ International Court of Justice, Whaling in the Antarctic (Australia v. Japan: New Zealand Intervening), Judgment 31 March 2014. See E Cannizzaro, 'Proportionality and Margin of Appreciation in the Whaling Case: Reconciling Antithetical Doctrines?'European Journal of International Law 2742016 1061-1069.

${ }^{52}$ See on the IACtHR: B Duhaime, 'Subsidiarity in the Americas. What Room Is There for Deference in the Inter-American System?' in L Gruszczynski and WG Werner (eds), Deference in international courts and tribunals : standard of review and margin of appreciation (Oxford University Press, Oxford 2014) 289-315; N Tsereteli, 'Emerging doctrine of deference of the Inter-American Court of Human Rights?'International Journal of Human Rights 2082016 1097-1112; and A Follesdal, 'Exporting the margin of appreciation: Lessons for the Inter-American Court of Human Rights'International Journal of Constitutional Law 1522017 359-371. On the 
Standards of review, like the margin of appreciation, cannot be found in the Vienna Convention or in general treaty law. The reason is that such standards does not say anything about how treaties should be interpreted. What the margin of appreciation does, is to regulate the interpretational competence between the ECtHR and national organs, especially national courts.

Nor can we find references to the margin of appreciation in the text of the ECHR. But the margin has been practiced by the Court since the classic Handyside case in 1976. In this case, the Court pointed out that the machinery of protection established by the ECHR 'is subsidiary to the national systems safeguarding human rights' and that ' $[\mathrm{b}] \mathrm{y}$ reason of their direct and continuous contact with the vital forces of their countries, State authorities are in principle in a better position than the international judge to give an opinion on the exact content of these [moral] requirements as well as on the "necessity" of a "restriction" or "penalty" intended to meet them. ${ }^{53}$

The margin of appreciation was recognized by member States in the Brighton Declaration which '[w] elcomes the development by the Court in its case law of principles such as subsidiarity and the margin of appreciation, and encourages the Court to give great prominence to and apply consistently these principles in its judgments' ${ }^{54}$ The margin has also been acknowledged in the subsequent Brussels ${ }^{55}$ and Copenhagen Declarations. Furthermore, the new Protocol 15 expressly supports the margin of appreciation. ${ }^{56}$

The margin of appreciation as applied by the ECtHR has distinct features compared to standards of review applied by domestic courts and by other international tribunals, reflecting its application to the field of human rights in the context of European democracies. The Court has in A and Others (2009) expressly distinguished the deference represented by the margin of appreciation from standards of review applied in a domestic setting:

The doctrine of the margin of appreciation has always been meant as a tool to define relations between the domestic authorities and the Court. It cannot have the same application to the relations between the organs of State at the domestic level..$^{57}$

The Court makes a distinction between its use of the margin of appreciation and what it has called the 'fourth instance' doctrine. The ECtHR has insisted that it is not a court of 'fourth

UN human rights treaty bodies: D McGoldrick, 'A Defence of the Margin of Appreciation and an Argument for its Application by the Human Rights Committee'International and Comparative Law Quarterly 6512016 21-60; and Y Shany, 'All Roads Lead to Strasbourg?: Application of the Margin of Appreciation Doctrine by the European Court of Human Rights and the UN Human Rights Committee'Journal of International Dispute Settlement 2017 .

${ }^{53}$ Handyside v United Kingdom (1976), Application no. 5493/72, paragraph 48.

${ }^{54}$ High Level Conference on the Future of the European Court of Human Rights. Brighton Declaration ( http://www.echr.coe.int/Documents/2012_Brighton_FinalDeclaration_ENG.pdf), paragraph 12 a).

55 The Brussels Declaration can be found at: http://www.echr.coe.int/Documents/Brussels Declaration ENG.pdf.

${ }^{56}$ Article 1 of Protocol No. 15 amending the Convention for the Protection of Human Rights and Fundamental Freedoms (CETS No. 2013) (not yet in force).

${ }^{57}$ A. and Others v. the United Kingdom, Application no. 3455/05 (2009), paragraph 184. 
instance', as recently expressed in Rohlena [Grand Chamber] (2015), where the Court pointed out that 'is primarily for the national authorities, notably the courts, to resolve problems of interpretation of domestic legislation. Its role is thus confined to ascertaining whether the effects of such interpretation is compatible with the Convention'. ${ }^{58}$ Thus, the margin of appreciation does not relate to the assessment of facts or interpretation of national law, but to the way in which the ECHR obligations are implemented in the relevant State.

The discretion allowed by the Court to the domestic level is governed by several factors. First, it depends on the right under examination. The Court will allow discretion in respect of ECHR Articles 8 to 11, which expressly permit a balancing between the right in question and other interest, such as allowing respect for private and family life if necessary in a democratic society. Other Articles, such as Article 3 on torture, allow no such discretion.

The permissible freedom of choice may also vary between the rights where interference is expressly allowed. For example, the Court has allowed a wide margin when it comes to the choice of 'general measures of economic or social strategy'. ${ }^{59}$ On the other hand, restrictions on the freedom of expression 'must be established convincingly'. ${ }^{60}$

The breadth of the margin may depend on the general international legal obligations in the area, ${ }^{61}$ as well as on whether there exist a European consensus on the issue. ${ }^{62}$ This means that European consensus can have a double function: it can provide a basis for evolutive interpretation binding on all member States, or, alternatively, it can provide one of the factors in determining the margin of appreciation in relation to an individual State, in its application of Convention rights.

The margin of appreciation applies to all constitutional organs, but the margin is not necessarily the same for the national legislature, the executive and domestic courts. For example, the Court stated in the İzzettin Doğan and others case [Grand Chamber] (2016) that '[i]n matters of general policy, on which opinions within a democratic society may reasonably differ widely, the role of the domestic policymaker should be given special weight' ${ }^{63}$ Such deference is based on the democratic character of decision-making in the member States.

National decision-making organs may enjoy a wider margin of appreciation if they are able to convince the ECtHR that they have taken into account relevant principles of interpretation, such as the principle of proportionality, as applied by the ECtHR. The Court stated for example in the von Hannover (No 2) case (2012) that ' [w] here the balancing exercise has been undertaken by the national authorities in conformity with the criteria laid down in the

\footnotetext{
${ }^{58}$ Rohlena $v$ the Czech Republic [GC], Application no. 59552/08 (2015), paragraph 51.

${ }^{59}$ Biao v Denmark [GC] (2016), Application no. 38590/10, paragraph 93.

${ }^{60}$ Pentikäinen v Finland [GC] (2015), Application no. 11882/10, paragraph 87.

${ }^{61}$ Naït-Liman v. Switzerland [GC] (2018), paragraph 173.

${ }^{62}$ See for example Bayatyan v. Armenia [GC] (2011), Application no. 23459/03: 'The Court may also have regard to any consensus and common values emerging from the practices of the States Parties to the Convention' (paragraph 122).

${ }^{63}$ İzzettin Doğan and others v Turkey [GC] (2016), Application no. 62646/10, paragraph 112 (emphasis added).
} 
Court's case-law, the Court would require strong reasons to substitute its view for that of the domestic courts. ${ }^{64}$ This has been called a 'procedural turn' or a 'process-based' review of national decision-making. ${ }^{65}$ However, it is of importance that the Court in its recent case law also has designated instances of bad faith implementation of ECHR standards. In such instances, the relevant States will not benefit from the deference represented by the margin of appreciation. ${ }^{66}$

States seem to be satisfied with the von Hannover approach, which has been confirmed in subsequent case law. ${ }^{67}$ The Copenhagen Declaration commends the Court for, in Articles such as 8 to 11 , generally not substituting 'its own assessment for that of domestic courts, unless there are strong reasons for doing so' if a balancing exercise has been undertaken at the national level 'in conformity with the criteria laid down in the Court's jurisprudence'. ${ }^{68}$

Yet, although the VCLT and the ECHR do not regulate the ECtHR's use of the margin of appreciation in the sense that these instruments provide guidance about interpretative outcomes, they - as well as general international law - restrict how far the Court can go in allowing discretion to States in their implementation of the ECHR, and how the margin should be applied.

First, it is essential that the freedom granted to States should not undermine effective protection of ECHR rights. This is reiterated in the Copenhagen Declaration, setting out that 'strengthening the principle of subsidiarity is not intended to limit or weaken human rights protection' ${ }^{69}$ The Court should even be required to go against a European consensus among States parties, if necessary to uphold effective protection of the Convention rights. It is also important that the Court does not abdicate from its role in guiding the interpretation of the different ECHR rights, not least in its interpretation of the Convention as a living instrument.

\footnotetext{
${ }^{64}$ von Hannover v. Germany (No. 2) [GC], Applications nos. 40660/08 and 60641/08 (2012), paragraph 107. ${ }^{65}$ R Spano, 'Universality or Diversity of Human Rights?: Strasbourg in the Age of Subsidiarity'Human Rights Law Review 2014 1-16, E Brems, 'Procedural Protection: An Examination of Procedural Safeguards Read Into Substantive Convention Rights' in E Brems and J Gerards (eds), Shaping Rights in the ECHR: The Role of the European Court of Human Rights in Determining the Scope of Human Rights (Cambridge University Press, Cambridge 2013) 137-162, M Saul, 'The European Court of Human Rights' Margin of Appreciation and the Processes of National Parliaments'Human Rights Law Review 154 2015 745-775, OM Arnardottir, 'The "procedural turn" under the European Convention on Human Rights and presumptions of Convention compliance'Icon-International Journal of Constitutional Law 1512017 9-35 and P Popelier and C Van De Heyning, 'Subsidiarity Post-Brighton: Procedural Rationality as Answer?'Leiden Journal of International Law 30 12017 5-23; R Spano, 'The Future of the European Court of Human Rights - Subsidiarity, Process-Based Review and the Rule of Law'Human Rights Law Review 2018 1-22.

${ }^{66}$ B Çal1, 'Coping with Crisis: Whither the Variable Geometry in the Jurisprudence the European Court of Human Rights?'Wisconsin International Law Journal 3522018 237-276, 269. See also Spano, 20-22.

67 Aksu v. Turkey [GC], Applications nos 4149/04 and 41029/04 (2012), paragraph 67; Couderc and Hachette Filipacchi Associés v. France [GC] Application no. 40454/07 (2015), paragraph 92; Satakunnan Markkinapörssi Oy and Satamedia Oy v. Finland [GC] (2017) Application no. 931/13, paragraph 164.

${ }^{68}$ Copenhagen Declaration, paragraph $28 \mathrm{c}$ ).

${ }^{69}$ Copenhagen, Declaration, paragraph 10.
} 
Moreover, it may be questioned how far the Court should go when it comes to reviewing procedures applied by domestic organs as a condition for allowing a wider margin of appreciation, especially to what extent the Court should determine that some procedures are more democratic than others. Finally, the differentiated use of the margin or the denial of its use should avoid challenging the general international law principle of the sovereign equality between States. However, this should not prevent the Court from distinguishing between loyal and disloyal implementation of the ECHR obligations. The Court should also ensure that national variations in the implementation of the ECHR does not threaten consistent interpretation of the Convention, and thereby undermines predictability and the rule of law.

\section{Systemic interpretation}

The VCLT Article 31(3)(c) requires that other rules of international law are taken into account when interpreting a treaty. The purpose is to promote the consistency of international law. This approach has been called 'systemic interpretation' by the Study Group of the International Law Commission on the Fragmentation of International Law. ${ }^{70}$

The ECtHR has expressed its general commitment to interpreting the ECHR consistent with other international obligations. In the Tanase case (2010), the Court said that it 'must take into account relevant international instruments and reports, and in particular those of other Council of Europe organs. ${ }^{71}$ The Court stated in the National Union case (2014) that account should be taken of Article 31(3)(c) and that this applies 'in particular [to] the rules concerning the international protection of human rights. ${ }^{72}$ The Court emphasized in Hassan (2014) that it 'has made it clear on many occasions that the Convention must be interpreted in harmony with other rules of international law'. Furthermore, '[ $\mathrm{t}]$ he Court must endeavour to interpret and apply the Convention in a manner which is consistent with the framework under international law delineated by the International Court of Justice. ${ }^{73}$ In Magyar Helsinki Bizottság [Grand Chamber] 2016 the Court stated that 'the Convention cannot be interpreted in a vacuum and must, in accordance with the criterion contained in Article 31(3)(c) of the Vienna Convention ... be interpreted in harmony with other rules of international law, of which it forms part. ${ }^{74}$ This was recently conformed in the Naït-Liman case [Grand Chamber] (2018), where the Court held that 'account should be taken, as indicated in Article $31 \S$ (3)(c), of "any relevant rules of international law applicable in the relations between the parties", and in particular the rules concerning the international protection of human rights'. ${ }^{75}$

\footnotetext{
${ }^{70}$ Martti Koskenniemi, Fragmentation of International Law. Difficulties Arising from Diversification and Expansion of International Law. Report of the Study Group of the International Law Commission (The Erik Castrén Institute Research Reports 21/2007 Helsinki, at 243-244 (paragraphs 479-480).

${ }^{71}$ Tanase v. Moldova, [GC], Application no. 7/08, paragraph 176 (emphasis added).

${ }^{72}$ National Union of Rail, Maritime and Transport Workers v. the United Kingdom, Application no. 31045/10, paragraph 76.

${ }^{73}$ Hassan, paragraph 102 (emphasis added).

${ }^{74}$ Magyar Helsinki Bizottság v. Hungary [GC] (2016), Application no. 18030/11, paragraph 138.

${ }^{75}$ Naït-Liman v. Switzerland, paragraph 174.
} 
A systemic approach is also reflected in the Court's practice. ${ }^{76}$ For example, it has used customary international law in determining the scope of its jurisdiction and of State responsibility. The Court accepted State immunity in the Al-Adsani case (2001) ${ }^{77}$ and the immunity of the United Nations in Stichting Mothers of Srebrenica and others (2013) ${ }^{78}$ The Court applied the general rules on attribution of responsibility between the United Nations and member States contributing with military forces in the Behrami and Saramati case (2007) ${ }^{79}$ The issue of effects of reservations to treaties should be mentioned, as an instance of the Court challenging the well-established opinion in general international law. However, the Belilos [Plenary] (1988) case $^{80}$ and the Court's subsequent practice on this issue is also an example of its influence on general international law. ${ }^{81}$

Hassan is remarkable since it provides a rare example that the Court felt compelled to a restrictive interpretation of the ECHR based on other international instruments, i.e. the Third and Fourth Geneva Conventions on international humanitarian law. In this case, the Court harmonized ECHR Article 5 of the ECHR with these Conventions by allowing the taking prisoners of war and detention of civilians in international armed conflict. ${ }^{82}$ However, the Court added that the detention 'should be in keeping with the fundamental purpose of Article $5 \S 1$, which is to protect the individual from arbitrariness' ${ }^{83}$ Thus, the Court tried - as best possible - to realign the two regimes: the ECHR and international humanitarian law, but without allowing more restrictions on the ECHR than necessary. Hence, the Court balanced systemic interpretation against effective application of the ECHR. Four partly dissenting judges held that the Court should have given priority to the Convention in this conflict with international humanitarian law. ${ }^{84}$

However, it may be difficult to determine whether the purpose of the Court is to ensure consistency in accordance with Article 31(3)(c), or to promote evolutive interpretation in accordance with the living instrument doctrine. ${ }^{85}$ For example, the Court stated in the

\footnotetext{
${ }^{76} \mathrm{C}$ McLachland, 'The Principle of Systemic Integration and Article 31(3)(c) of the Vienna Convention'International and Comparative Law Quarterly 542005 279, 294, 304-306; V Tzevelekos, 'The Use of Article 31(3)(C) of the VCLT in the Case Law of the ECtHR: An Effective Anti-Fragmentation Tool or a Selective Loophole for the Reinforcement of Human Rights Teleology - Between Evolution and Systemic Integration'Michigan Journal of International Law 312010 621-690; K Dzehtsiarou, 'What is Law for the European Court of Human Rights?'Georgetown Journal of International Law 49 2018 89-134; and A Rachovitsa, 'The Principle of Systemic Integration in Human Rights International Law'International and Comparative Law Quarterly 6632017 557-588.

${ }^{77}$ Al-Adsani v. the United Kingdom, Application no. 35763/97 (2001)

${ }^{78}$ Stichting Mothers of Srebrenica and others v. the Netherlands, Application no. 65542/12 (2013).

${ }^{79}$ Behrami and Behrami v. France and Saramati v. France, Germany and Norway [GC] Applications no. 71412/01 and 78166/01.

${ }^{80}$ Belilos v, Switzerland [Plenary] (1988), Application no. 10328/83.

${ }^{81}$ See International Law Commission, Guide to Practice on Reservations to Treaties (2011), Yearbook of the International Law Commission, 2011, vol. II, Part Two, Rule 4.5.3.; ET Swaine in DB Hollis (ed) The Oxford Guide to Treaties (Oxford University Press, Oxford Treaty Reservations) 277-301, 298.

${ }^{82}$ Hassan, paragraph 104.

${ }^{83}$ Hassan, paragraph 105.

${ }^{84}$ Hassan, partly dissenting opinion of judge Spano joined by judges Nicolaou, Bianku and Kalaydjieva, paragraph 19.

85 Tzevelekos, 661, 664.
} 
National Union case that '[i]t would be inconsistent with this method [i.e. the method used in Demir and Baykara] for the Court to adopt in relation to Article 11 an interpretation of the scope of freedom of association of trade unions that is much narrower than that which prevails in international law. ${ }^{86}$ This goes further than avoiding legal inconsistencies between the ECHR and other legal instruments, and shows that the evolutive function of other treaties may be more dominant than achieving coherence through systemic interpretation.

Questions of consistency does not only arise with respect to the ECHR and other rules of international law, but also with decisions by international organizations, particularly by the EU and by the UN Security Council. Relevant issues include whether the Court should use systemic interpretation based on the VCLT Article 31(3)(c); or, alternatively, standards of review; or application of rules on superiority between different legal regimes - or a combination of these approaches.

The Bosphorus standard was established by the Court in a case from 2005 regarding national implementation of EU law. ${ }^{87}$ This case concerned whether the impounding of an aircraft based on EU sanctions rules violated ECHR Article 1 of Protocol 1 on the protection of property. The ECtHR found that the EU protects human rights 'in manner which can be considered at least equivalent to that for which the Convention provides'. Therefore, the Court applied a presumption that a member State respects the Convention obligations when it 'does no more than implement legal obligations flowing from its membership of the organisation'.

However, this presumption 'can be rebutted if, in the circumstances of a particular case, it is considered that the protection of Convention rights was manifestly deficient. In such cases, the interest of international cooperation would be outweighed by the Convention's role as a "constitutional instrument of European public order" in the field of human rights" ${ }^{88}$ This standard has been followed in subsequent case law, including the Michaud case (2012) ${ }^{89}$ and the recent Avotiņ̌ case (2016). ${ }^{90}$

Like the margin of appreciation, the Bosphorus standard concerns the standard of review in relation to decisions by national organs - here in their implementation of EU law, rather than a principle of interpretation. As to the legal basis for its reasoning, the Court referred to the need to interpret the ECHR in the light of 'any rules and principles of international law applicable in relations between the Contracting Parties (Article $31 \S 3$ (c) ...) ... The Court has also long recognized the growing importance of international cooperation and of the consequent need to secure the proper functioning of international organisations... ${ }^{91}$ But, on the other hand, '... absolving Contracting States completely from their Convention responsibility in the areas covered by such a transfer would be incompatible with the purpose

\footnotetext{
${ }^{86}$ National Union of Rail, Maritime and Transport Workers, paragraph 76.

${ }^{87}$ Bosphorus Hava Yollari Turizm Ve Ticaret Anonim Sirketi v. Ireland [GC] (2005), (Application no. 45036/98).

${ }^{88}$ Bosphorus, paragraphs 155-156.

${ }^{89}$ Michaud v. France (2012), Application no. 12323/11.

${ }^{90}$ Avotiňš v. Latvia [GC] (2016), Application no. 17502/07.

${ }^{91}$ Bosphorus, paragraph 150.
} 
and object of the Convention; the guarantees of the Convention could be limited or excluded at will, thereby depriving it of its peremptory character and undermining the practical and effective nature of its safeguards'. ${ }^{92}$

The Bosphorus standard represents a different balance between respect for national decisionmaking and effective human rights protection than the margin of appreciation. The Court has determined a higher threshold for intervening when EU rules are implemented by member States. This is based on the additional factors represented by systemic interpretation (VCLT, article $31(3)(c))$ and recognition of the need for cooperation through international organizations.

But this more lenient standard raises issues about the 'practical and effective' protection by the ECHR in light of EU's wider objective of further economic and legal integration. One essential aspect is to what extent the ECtHR accepts the increasingly applied principle of 'mutual trust', whereby EU States should respect decisions in other member States without further examination.

The principle of mutual trust was essential in the European Court's Advisory Opinion 2/13 of 2014 on EU accession to the ECHR. ${ }^{93}$ The subsequent Avotiňš case concerned Latvian enforcement of a contract based on a judgment in Cyprus. The ECtHR accepted the mutual trust principle in this case, but commentators argue that the tone of the Court was more critical than in earlier case law. This could signal that the Bosphorus principle would not prevent the Court from stricter review of mutual trust cases in the future. ${ }^{94}$

The Al-Dulimi case [Grand Chamber] (2016) ${ }^{95}$ shows a different dilemma, i.e. the relationship between the UN Charter obligations - which have priority according to article 103 of the Charter - and the rights set out in the ECHR. The Court could have applied the lex superior principle and concluded that Security Council resolutions prevail over the ECHR. Instead, the Court applied a dual approach. On the one hand, it held that there was a presumption that Security Council resolutions could not have been meant to violate international human rights. ${ }^{96}$ But, furthermore, it argued that the ECHR is a constitutional instrument of the European order, and that States therefore have to respect the rule of law, and therefore avoid arbitrariness. ${ }^{97}$ It held that a State adding a person to a terrorist sanction list 'without first ensuring - or being able to ensure - that the listing is not arbitrary will engage responsibility under Article 6 of the Convention'. ${ }^{98}$

\footnotetext{
${ }^{92}$ Bosphorus, paragraph 154.

${ }^{93}$ Opinion 2/13 of the Court (Full Court) 18 December 2014, paragraph 168, 191 and 258.

${ }^{94}$ D Dusterhaus, 'The ECtHR, the CJEU and the AFSJ: A Matter of Mutual Trust'Eur. Law Rev. 4232017388 -

401, 396: LR Glas and J Krommendijk, 'From Opinion 2/13 to Avotiňš : Recent Developments in the

Relationship between the Luxembourg and Strasbourg Courts'Human Rights Law Review 173 2017 567-587, 586.

${ }^{95}$ Al-Dulimi and Montana Management Inc. v. Switzerland [GC] 2016.

${ }^{96}$ Al-Dulimi, paragraph 140.

${ }^{97}$ Al-Dulimi, paragraph 145.

${ }^{98}$ Al-Dulimi, paragraph 147.
} 
It could be asked whether such a strong presumption in favour of human rights in reality gives these rights - rather than the UN Charter obligations - the status of lex superior, without the Court arguing that the relevant human rights obligations enjoy the status of jus cogens.

Furthermore, one may ask whether the 'constitutional instrument' argument has similarities to the Kadi approach by the Court of Justice of the European Union, basing its priority for human rights obligations on a dualist approach, i.e. that EU law respects human rights whether or not there are international obligations following from implementation of Security Council resolutions. ${ }^{99}$ Although there was only one dissenting and one partly dissenting judges in the Al-Dulimi, the variety of reasoning in the several concurring opinions shows that the Court may not have settled on an ultimate and sustainable approach on how it shall deal with the relationship between Security Council resolutions and the ECHR. This means that, while the VCLT Article 31(3)(c) gives guidance, the Al-Dulimi indicates that the ECtHR will emphasize the effective protection of ECHR rights when confronted with Security Council resolutions. Yet, the legal approaches applied in such control is not yet sufficiently clarified.

\section{Conclusions}

The ECtHR has accepted that the Vienna Convention on the Law of Treaties applies to the interpretation of the ECHR. The VCLT interpretation principles give considerable flexibility, and do not prevent the Court from upholding the ECHR protection, i.e. there is no contradiction between the VCLT and the Convention as an effective and timely human rights treaty. As emphasized in the Copenhagen Declaration, this reliance on recognized principles of treaty interpretation bolsters the legitimacy of the Court, as seen by member States.

However, a core issue is how far the ECtHR should go in its interpretation. I have argued that the Court, in its effective interpretation, should not interfere too much through incremental requirements in the domestic legal systems, and should avoid interfering in issues that are not of such a gravity to merit international supervision. Furthermore, the Court should distinguish clearly between evolutive interpretation based on Article 31(1), i.e. on the ECHR's object and purpose, and, on the other hand, such interpretation based on Article 31(3)(b) and 31(3)(c). In its evolutive interpretation, the Court should also clarify its use of a European consensus and abandon its unfettered discretion in using international legal instruments for this purpose.

It is also crucial to distinguish between principles of interpretation and standards of review. The margin of appreciation is an aspect of subsidiarity. It represents a standard of review applied in the Court's assessment of national implementation of the ECHR. The Court's deference to domestic organs means that it does not express its opinion on the correct interpretation of the Convention, as long as these organs apply the methods of interpretation developed by the Court. However, principles of interpretation establish how far the Court should go and the way in which it uses the margin of appreciation. The Court should ensure that deference to domestic decision-makers does not undermine effective implementation of

\footnotetext{
99 Joined Cases C-402/05 P and C-415/05 P, Kadi \& Al Barakaat Int'l Found. v. Council \& Comm'n, 2008 E.C.R. I-06351; Joined Cases C- 584/ 10 P, C- 593/ 10 P, and C- 595/ 10 P European Commission and others v Kadi [2013] ECR I- 0000.
} 
the ECHR. It is also important that the margin is consistently applied and that the Court retains its role as the final arbiter of how the ECHR should be interpreted. The Court must ensure equal treatment among States with respect to benefitting from the margin of appreciation.

The Court applies a systemic approach, in accordance with the VCLT Article 31(3)(c) in relation to customary international law as well as other treaties. However, the relationship between the ECHR obligations and decision by international organs, especially the EU and Security Council, raise particular challenges. The Bosphorus principle, used with respect to domestic implementation of EU law, represents a standard of review. This principle means more deference by the ECtHR than the margin of appreciation generally used in relation to domestic decision-making. In the future, the ECtHR may apply stricter scrutiny of national implementation of EU decisions in order to ensure the effectiveness of the ECHR obligations. There is also some uncertainty in the Court's approach to review of implementation of the formally superior Security Council resolutions. The Court may need to develop its approaches to national implementation of such decisions. 